\title{
Respon Kelompok Ternak Sidodadi 2 di Kepahiang Bengkulu terhadap Pelatihan Pembuatan Medicated Blok yang Mengandung Antelmentika Alami untuk Mencegah Helminthiasis
}

\author{
Response of Livestock Group in Sidodadi 2 Kepahiang Bengkulu on Training of Making \\ Medicated Block Containing Natural Anthelmentic to Reduce Helminthiasis
}

\section{T. Suteky, Dwatmadji, dan E. Soetrisno}

Jurusan Peternakan, Fakultas Pertanian, Universitas Bengkulu.

Jl. W.R. Supratman Kandang Limun, Bengkulu 38371. Tel./Fax. +62-736-21290,

Koresponden e-mail : tatiksuteky.2008@yahoo.com

\begin{abstract}
This research aimed to determine farmer's knowledge on helminthiasis and their control using Medicated block after introducing this block. Medicated block is a feed supplement containing natural anthelmintic. Purposed sampling was used and interviews was conducted on 25 farmer who joined on Sidodadi livestock group. Structured questionnaires were designed to know the knowledge of farmer on helmint infections, helmint control and farmer perception on Medicated block. The questionnaires were administered from late July to October 2016, pre-post test were conducted to examine their farmer knowledge. Data collected was descriptively analized. Result showed that more than $60 \%$ the farmer in productive of age, livestock owner ship 4.5, farmer experiences about 5.9 years. Results also showed that the farmer's knowledge on helminthiasis were increased from 14.92 to 39.72 , the efectivity of training was 88.07. Our fining also found that the knowledge about medicated block were inclined 12.80 (4.72 to 17.52) the efectivity of training was 87.6.
\end{abstract}

Key words : helminthiasis, block, natural anthelmentic

\begin{abstract}
ABSTRAK
Tujuan penelitian ini adalah untuk mengevaluasi pengetahuan peternak terhadap penyakit cacing dan penggunaan medicated block sebagai anti cacing/ anthelmentika. Metode pengambilan sampel dilakukan secara purposive sebanyak 25 orang anggota kelompok ternak Sidodadi 2 dipilih sebagai responden. Data yang diambil adalah aspek perubahan pengetahuan yang di evaluasi dengan pre-post test, quisioner diberikan untuk melihat karaketristik responden. Hasil penelitian menunjukkan bahwa lebih dari $60 \%$ peternak berusia produktif, kepemilikan ternak sekitar 4,5 ekor, lama beternak 5,9 tahun, Hasil penelitian menunjukkan bahwa treatment (penyuluhan dan pelatihan) penyakit cacingan dapat meningkatkan pengetahuan dari 14,92 (tidak tahu) menjadi 39,72 (tahu) dengan efektifitas penyuluhan yang dilakukan sebesar 88,07, sedangkan pengetahuan tentang medicated block meningkat sebesar 12,80 (dari 4,72 menjadi 17,52) dengan efektivitas penyuluhan sebesar 87,6.
\end{abstract}

Kata kunci: helminthiasis, blok, anthelmentika alami

\section{PENDAHULUAN}

Helminthiasis merupakan problem kesehatan terbesar yang dihadapi ternak ruminansia baik di negara tropis maupun sub-tropis (Bekele et al., 1992; Wildeusand dan Zajac, 2005; Suteky et al., 2014 dan 2016). Penyakit ini juga menyerang ternak di negara maju meskipun manajemennya sudah sangat memadai seperti peternak di Inggris, Perancis, Belanda dan Amerika (Hoste et al., 2002; Jackson dan Coop, 2000). Haemonchus contortus merupakan helmint yang menempati urutan teratas menyebabkan kerugian ekonomi (Perry et al., 2002; Kaplan, 2006), diikuti dengan Trichostrongylus.

Suteky dan Dwatmadji menemukan bahwa experimental 
helminthiasis yang di akibatkan oleh Haemonchus contortus dapat menyebabkan kematian ternak sebesar $66,7 \%$ mulai dari 3-6 minggu pasca infeksi. Pada infeksi berat kematian dapat mencapai $80 \%$, bahkan pengobatan dengan ivermectin tidak mampu sepenuhnya menurunkan mortalitasnya (Suteky dan Dwatmadji, 2015). Kematian ternak terjadi karena Haemonchus contortus dapat menghisap darah sampai 0,05 ml per ekor per hari (Soulsby, 1982), pada infestasi berat $1 / 10$ volume darah ternak dapat berkurang. Suteky dan Dwatmadji (2015) menemukan penurunan PCV sebesar 50,88 \%, sedangkan penurunan haemoglobin mencapai 53,54\% akibatnya ternak menderita anemia berat yang diikuti dengan kematian.

Anthelmentika modern seperti ivermectin merupakan obat anti Helminthiasis yang sampai saat ini paling handal, namun harganya yang cukup mahal sehingga obat ini tidak terjangkau oleh petani di pedesaan. Oleh sebab itu perlu dicari alternatif solusi menggunakan antelmentika yang murah dan mudah didapat. Suteky dan Dwatmadji (2011) melaporkan bahwa ekstrak Melastoma malabatricum secara in vitro mampu menghambat egg hacth assay and larva development assay. Suteky dan Dwatmadji (2016) menemukan pemberian ekstrak Melastoma malabatricum dan pakan suplemen dapat menurunkan angka mortalitas dan meningkatkan Average Daily Gain (ADG). Penduduk Desa Tugu Rejo memelihara ternak sebagai usaha sambilan, rendahnya produktivitas ternak ruminansia merupakan persoalan umum yang terjadi. Hasil analisis situasi menunjukkan bahwa belum optimumnya produktivitas ternak salah satunya kurangnya pengetahuan peternak dalam mengenali secara dini ternak nya yang sakit. Kasus kematian ternak tertinggi ditandai dengan ternak yang kurus, anoreksia, pembengkakan diwajah, bulu kusam, gejala tersebut merupakan indikasi ternak terserang penyakit parasit.

Kondisi iklim di Bengkulu sangat rentan terhadap penyakit parasit berbagai jenis nematoda (mix-gastro intestinal parasite) terutama Haemonchus contortus. Mengingat kerugian ekonomi akibat penyakit ini sangat tinggi maka penyakit parasit ini harus segera di tangani secara komprehensif. Tujuan penelitian ini adalah untuk meningkatan wawasan peternak dalam manajemen kesehatan ternak dan pengenalan pengendalian penyakit helminthiasis dengan menggunakan anthelmentika alami dalam bentuk blok (medicated block).

\section{MATERI DAN METODE}

Kegiatan penelitian untuk mengevaluasi respon peternak terhadap penyuluhan tentang Helminthiasis dan pelatihan pembuatan blok yang mengandung anthelmentika alami dilaksanakan di kelompok ternak Sidodadi 2 Desa Tugu Rejo Kecamatan Kabawetan berada di wilayah administrasi Kabupaten Kepahiang. Penelitian dilakukan pada bulan JuniNopember 2016. Responden adalah anggota kelompok ternak Sidodadi 2 sebanyak 25 orang peternak. Data primer diperoleh dengan cara observasi dan wawancara dengan bantuan kuisioner yang terstruktur, pertanyaan terkait dengan keadaan umum responden. Untuk mengetahui pengetahuan peternak terhadap treatment yang telah dilakukan pre-post test. Untuk mengetahui respons 
setiap pertanyaan telah ditetapkan parameternya dengan kriteria: skor 5 (baik/tahu) 3 (sedang) dan 1 (kurang). Efektifitas penyuluhan dihitung berdasarkan metode Susanto dan Suryana (2014). Dalam penelitian juga dilakukan peninjauan lapangan untuk melihat kondisi ternak dan kandangnya.

\section{HASIL DAN PEMBAHASAN}

\section{Keadaan Umum Lokasi Penelitian}

DesaTugu Rejo terdiri atas 4 RT, luas wilayah \pm 311 hektar jarak dari Kantor Desa ke Kota Kecamatan adalah $\pm 5 \mathrm{Km}$, ke Kota Kabupaten berkisar antara \pm 12 Kilometer. Dilihat dari batas wilayah administrasi, Desa Tugu Rejo berbatasan dengan desa Mekar Sari (sebelah utara), Sebelah Selatan: Tangsi Duren, Sebelah Barat: Perbatasan kebun teh, Sebelah Timur: Suka Sari. Secara geografis, Desa Tugu Rejo adalah merupakan wilayah pergunungan/dataran dengan ketinggian 1200 mdpl yang terdiri dari persawahan, pertanian palawija dan perkebunan. Jumlah penduduk Desa Tugu Rejo sampai dengan akhir tahun 2014 sebesar 642 jiwa dengan jumlah Kepala Keluarga sebanyak 166, dengan mata pencaharian umumnya sebagai petani kopi, sayuran dan sebagai pekerjaan sambilan adalah beternak. Jumlah sapi di desa Tugu Rejo 90 ekor, kerbau 15 ekor, kambing 90 ekor dan kelinci 50 ekor.

Kelompok Tani "Sidodadi 2" berkedudukan di Desa Tugu Rejo Kecamatan Kabawetan Kabupaten Kepahiang Provinsi Bengkulu. Kelompok Tani "Sidodadi 2" didirikan secara resmi pada tanggal 18 Maret 2009, dengan motivasi dan semangat bersama untuk maju dan mengembangkan usaha peternakan.Upaya tersebut nampak nyata dengan meningkatnya jumlah anggota kelompok dari 11 menjadi 30 orang, beternak merupakan pekerjaan sambilan sebagai petani kopi dan sayuran. Dengan melibatkan anggota kelompok yang aktif maka kegiatan ini menjadi lebih efektif dan efisien dalam memecahkan masalah kelompok. Menurut Rochaeni (1995) pendekatan kelompok lebih efisien karena petani dapat belajar bersama untuk memecahkan permasalahan yang dihadapi menyangkut usaha taninya.

\section{Keadaan Umum Responden}

Tingkat pendidikan akan mempengaruhi dalam penerimaan dan adopsi informasi serta teknologi. Tingginya pendidikan akan mempengaruhi tingginya kualitas sumberdaya manusia yang pada gilirannya akan semakin tinggi pula produktivitas kerja yang dilakukannya. Dengan tingginya produktivitas kerja diharapkan kinerja usaha peternakan akan semakin berkembang. Tabel 1 memperlihatkan karakteristik kelompok ternak Sidodadi 2, hanya $20 \%$ responden berpendidikan sampai tingkat SMA. Apabila dikaitkan dengan umur peternak yang lebih dari $60 \%$ usia produktif maka pengembangan peternakan masih sangat memungkinkan hal ini ditunjang dengan potensi sumber pakan sangat melimpah.

Beternak merupakan pekerjaan sambilan hal ini terlihat dari rataan kepemilikan ternak yang masih dalam kategori skala kecil yakni 4,5 ekor. Riadi et al. (2014) menyatakan bahwa usaha peternakan sebagai sambilan apabila jumlah ternak sapi yang dipelihara berkisar antara 3-6 ekor. Kelompok Tani "Sidodadi 2" didirikan pada tahun 2009, pada awalnya kelompok tani ini didirikan agar bisa mendapat bantuan ternak sapi dari 
pemerintah daerah (Dinas Peternakan) Kabupaten Kepahiang. Dengan demikian responden mulai beternak sekitar tahun 2010-2011 ketika mendapatkan bantuan ternak sapi. Dengan kata lain peternak sudah memiliki pengalaman dan ketrampilan yang cukup memadai dalam memelihara ternaknya.

Tabel 1. Karakteristik peternak kelompok Sidodadi 2

\begin{tabular}{lll}
\hline No & Uraian & Persentase \\
\hline 1 & Tingkat Pendidikan & \\
& SD & 53,33 \\
& SMP & 26,67 \\
& SMA & 20,00 \\
& Sarjana & 0,00 \\
2 & Umur Peternak & \\
& < 40 Tahun & 33,33 \\
& 40-50Tahun & 33,33 \\
& 50-60 Tahun & 20,00 \\
& >60 tahun & 13,34 \\
3 & Pekerjaan pokok & 90 \\
& Bertani & 10 \\
& Non-petani & Rataan dan sd \\
& & $4,5 \pm 1,37$ \\
4 & Kepemilikan ternak & \\
5 & Pengalaman beternak & $5,9 \pm 1,99$ \\
6 & Anggota Keluarga & $3,63 \pm 0,64$ \\
\hline
\end{tabular}

Pada Tabel 2 terlihat bahwa 60\% peternak menyatakan ternaknya pernah terserang penyakit cacing, terserang kutu/caplak (44\%) kembung (16\%), luka $24 \%$, sedangkan $48 \%$ terserang penyakit lain yang peternak tidak tahu penyebabnya. Cacingan atau helminthiasis merupakan penyakit yang paling sering menyerang ternak, hal ini sesuai dengan hasil penelitian Suteky et al. (2016) penyakit ini dapat ditemui di 11 kecamatan di Manna dengan morbiditas mencapai $90 \%$.

Hasil pengamatan lapangan menunjukkan infestasi ektoparasit terutama disebabkan oleh caplak, jenis caplak yang paling banyak menyerang sapi adalah Boophilus microplus), caplak bisa mengisap darah, merusak kulit menimbulkan kegatalan dan dapat bertindak sebagai vektor (pemindah) berbagai penyakit virus, bakteri, protozoa, riketsia. Hasil tinjauan lapangan juga menunjukkan 0-40\% kambing terkena scabies, beberapa ternak sapi juga pernah terserang Demam tiga hari (Bovine Ephemeral Fever), sedangkan luka pada ternak kebanyakan disebabkan karena bentuk kandang yang salah.

Tabel 2. Pengetahuan peternak tentang penyakit ternak

\begin{tabular}{clc}
\hline No & Uraian & Persentase $(\%)$ \\
\hline 1 & Penyakit yang sering menyerang ternak & \\
& Cacingan & 60,0 \\
& Caplak/kutu & 44,0 \\
& Kembung & 16,0 \\
& Luka & 24,0 \\
& Penyakit lain & 48,0 \\
2 & Penanganan ternak sakit & 40,0 \\
& Diobati sendiri & 8,0 \\
& Lapor ke Manteri hewan/PPL & 16,0 \\
& Lapor ke pengurus kelompok & 36,0 \\
\hline
\end{tabular}

Tabel 3 menunjukkan skore rata-rata pengetahuan peternak tentang gejala penyakit cacingan, pencegahan penyakit cacing, dan pemanfaat herbal untuk cacingan adalah 1,66 dan treatment yang diberikan pada peternak berupa 
penyuluhan, diskusi dan kunjungan lapangan mampu meningkatkan pengetahuannya menjadi 4,41 sehingga ada kenaikan sebanyak 2,76. Apabila dihitung efektifitas penyuluhan yang dilakukan nilainya 88,07 termasuk kategori efektif. Gejala penyakit cacingan yang paling diketahui peternak adalah kurus, diharapkan peningkatan pengetahuan tentang gejala penyakit cacingan dapat mencegah ternaknya terkena penyakit cacing. Suteky dan Dwatmadji (2011 dan 2016) menemukan helminthiasis dapat menyebabkan penurunkan $\mathrm{Hb}$ dan PCV sehingga ternak menjadi pucat, nafsu makan turun, bulu kusam dan penurunan berat badan (kurus).

Tabel 3. Hasil pre-post test pengetahuan peternak tentang penyakit cacing

\begin{tabular}{lccc}
\hline \multicolumn{1}{c}{ Pertanyaan } & Pre-test & Post-test & Peningkatan \\
\hline Tanda ternak terkena cacingan & & & \\
Kurus & 2,04 & 4,60 & 2,56 \\
Nafsu makan turun & 1,96 & 4,28 & 2,32 \\
Bulu kusam & 1,80 & 4,44 & 2,64 \\
Mata pucat & 1,24 & 4,36 & 3,12 \\
$\quad$ Mencret & 1,48 & 4,52 & 3,04 \\
Pencegahan penyakit cacing & & & \\
$\quad$ Diberi obat cacing & 2,12 & 4,52 & 2,40 \\
$\quad$ Sanitasi & 1,16 & 4,20 & 3,04 \\
Pemanfaat herbal untuk pengobatan cacingan & & & \\
Memanfaatkan Herbal & 2,12 & 4,52 & 2,40 \\
$\quad$ Tahu pemanfaat daun Senggani & 1,00 & 4,28 & 3,28 \\
\hline Jumlah & 14,92 & 39,72 & 24,80 \\
Rata-rata & 1,66 & 4,41 & 2,76 \\
\hline
\end{tabular}

Pada Tabel 3 menunjukkan bahwa pada umumnya peternak tidak tahu metode pencegahan cacingan. Hasil diskusi dengan peternak, mereka juga sangat antusias untuk mengetahui siklus hidup cacing dan cara penularan penyakit cacing, diharapkan setelah diskusi peternak mampu mencegah cacingan dengan memperhatikan manajemen termasuk sanitasi kandangnya. Hasil penelitian juga menunjukkan bahwa $100 \%$ peternak belum pernah memanfaatkan daun senggani (Melastoma malabatricum) untuk pengobatan ternak. Manfaat Melastoma malabatricum sebagai tumbuhan obat tidak hanya dilaporkan di Indonesia tetapi juga dilaporkan peneliti dari Malaysia dan India sebagai anti diare, anti spasmodik, anti cacing, anti luka, dan juga memiliki efek anti sitotoksik (Hussain et al., 2008; Lohezic-Le et al., 2002; Sunilson et al., 2009, Osman et al., 2002; Suteky and Dwatmadji, 2011; dan 2016; Suteky et al., 2014).

Tabel 4. Hasil pre-post test pengetahuan peternak tentang Medicated Block

\begin{tabular}{lccc}
\hline \multicolumn{1}{c}{ Pertanyaan } & Pre-test & Post-test & Peningkatan \\
\hline Medicated Block & & & \\
Pengertian Medicated Block & 1,24 & 4,44 & 3,20 \\
Manfaat Medicated Block & 1,16 & 4,52 & 3,36 \\
Pembuatan Medicated Block & 1,16 & 4,20 & 3,04 \\
Pemberian Medicated Block & 1,16 & 4,36 & 3,20 \\
\hline Jumlah & 4,72 & 17,52 & 12,80 \\
Rata-rata & 1,18 & 4,38 & 3,20 \\
\hline
\end{tabular}


Komposisi Medicated block yang diberikan untuk pelatihan adalah dedak padi $20 \%$, molases $25 \%$, Urea $10 \%$, semen $10 \%$, mineral mix $1 \%$, semen $20 \%$, ekstrak Melastoma 5\%, garam 4\%, cassava flour $5 \%$. Blok dibuat dengan cara yang sederhana agar lebih mudah diimplementasikan, blok dibuat tanpa menggunakan proses pressing tetapi memanfaatkan bekas botol minuman yang sangat mudah didapatkan. Hasil penelitian menunjukkan bahwa hanya $20 \%$ peternak mengetahui tentang pakan tambahan yang berbentuk blok, namun peternak masih belum mengetahui tentang medicated block. Tabel 4 memperlihatkan bahwa terjadi peningkatan pengetahuan tentang medicated block dari 1,18-4,38 setelah penyuluhan dan mencoba membuat blok. Apabila dihitung efektifitas treatment (penyuluhan dan pelatihan) yang diberikan nilainya 87,6 .

\section{KESIMPULAN}

Hasil penelitian menunjukkan bahwa treatment (penyuluhan dan pelatihan) penyakit cacingan dapat meningkatkan pengetahuan dari 14,92 (tidak tahu) menjadi 39,72 (tahu) dengan efektifitas penyuluhan yang dilakukan sebesar 88,07, sedangkan pengetahuan tentang medicated block meningkat sebesar 12,80 (dari 4,72 menjadi 17,52) dengan efektivitas penyuluhan sebesar 87,6.

\section{UCAPAN TERIMAKASIH}

\section{Terimakasih kepada DP2M} Kemenristek Dikti yang telah memberi dana kegiatan PPM-IbM dengan kontrak No 918/UN30.15/PM/2016 sehingga penyuluhan dan pendampingan peternak dalam rangka implementasi pembuatan blok yang mengandung anthelmentika alami dapat dilakukan dengan baik dan lancar.

\section{DAFTAR PUSTAKA}

Bekele, T., T. Woldeab, A. Lahlou-Kassi and J. Sherington. 1992. Factors affecting morbidity and mortality on-farm and on station in the Ethiopian highland sheep. Acta Tropica. 52 (2-3): 99-109.

Hoste, H., C. Chartier and Y. Le Frileux. 2002. Control of gastrointestinal parasitism with nematodes by treating the host category at risk. Veterinary Research. 33(5): 531545.

Hussain, F., M. A. Abdulla, S. M. Noor, S. Ismail and H. M. Ali. 2008. Gastroprotective effects of Melastoma malabathricum aqueous leaf extract against ethanol-induced gastric ulcer iin rats. American Journal of Biochemistry and Biotechnology 4 (4): 438-441.

Jackson, F. and R.L. Coop. 2000. The development of anthelmintic resistance in sheep nematodes. Parasitology 120 (7): 95 - 107.

Kaplan, R. M. 2006. Update on Parasite Kontrol in Small Ruminant Addressing the Challenges Posed By Multiple-Drug Resistant Worms. Proceedings of the American Association of Bovine Practitioners, Saint Paul, MN, September 21-23.

Lohezic-Le Devehat, F., A. Bakhtiar M, C. Bezivin, M. Amoros and J. Boustie. 2002. Antiviral and cytotoxic activities of some 
Indonesian plants. Fitoterapia. 73 (5) : 400-405.

Osman, K., H.I. Faridah, Z.A. Ibrahim dan A. Latif. 2002. A Guide book to medicinal plant of Perlis. 1 st edition, Jabatan Perhutanan Negeri Perlis, Kangar Perlis.

Perry, B.D., R.F. Randolph, J.J. McDermott, K.R. Sones and P.K. Thornton. 2002. Investing in animal health research to alleviate poverty. International Livestock Research Institute (ILRI), Nairobi, Kenya.

Riadi S, S. Nur dan Krismiwati. 2014. Faktor-Faktor yang Berpengaruh Terhadap Pendapatan Peternak Sapi Di Kabupaten Banyumas. Jurnal Ilmiah Peternakan 2(1): 313-318.

Rochaeni, S. 1995. Efektivitas metode penyuluhan terhadap peningkatan mutu dan hasil petani di Dusun Techno. Laporan Penelitian Fakultas Pertanian, Unpati, Ambon.

Susanto dan Suryana. 2014. Respon peternak terhadap pemberian urea molases multinutrient block (UMMB) sebagai pakan penguat pada sapi bali di desa sumber mulya Kecamatan pelaihari tanah laut. Prosiding Seminar Nasional "Inovasi Teknologi pertanian Spesifik Lokasi”, Banjarbaru 6-7 Agustus 2014.

Soulsby, E.J.L. 1982. Helminths, Protozoa and Arthropods of Domesticated Animal. 7th. Edition. Bailliere Tindall, London.

Sunilson, J.A.J, K. Anandarajagopal, A.V.A.G. Kumari and S. Mohan.
2009. Anti diarrheal activity of leaves of Melastoma malabathricum Linn. Indian Journal of Pharmaceutical Sciences, 71(6): 691-695.

Suteky, T. dan Dwatmadji 2009. Suplementasi pakan dengan fortifikasi anthelmentika alami untuk mengatasi infestasi Haemonchus sp dalam rangka mendukung sistem integrasi sawit ternak di Bengkulu. Laporan pengabdian pada masyarakat Hibah Pengabdian pada masyarakat Strategis Nasional.

Suteky, T. dan Dwatmadji. 2011. Anthelmentic Activity of Melastoma Malabatricum Extract on Haemonchus Contortus In Vitro. Asian Journal of Pharmaceutical and Clinical Research. supp 4: 6870 .

Suteky, T. and Dwatmadji. 2015. Ethnoveterinary technology for parasite dewormer to support goatoil palm integration in Bengkulu Indonesia. International Journal of Agriculture Technology 11(8): 2419-2424.

Suteky, T. and Dwatmadji. 2016. Effect of Melastoma Malabatricum And Feed Supplementation On Local Goat Infected With Haemonchus Contortus In Ruminant-Oil Palm Integrated

Suteky, T. 2016. Effect of Melastoma malabatricum and feed supplementation on local goat infected with Haemonchus contortus in Ruminant-Oil palm integrated System. International 
Journal of Agricultural Technology, 12 (7.1) :1567-1576.

Suteky, T., Dwatmadji and E. Sutrisno. 2014. The Potential Use of Melastoma Malabatricum Extract As Natural Anthelmintic Againts Haemonchus Contortus Of Goat For Small Farmer In Bengkulu. Presented in Regional Network on Poverty Eradication (RENPER) Banking University of Ho Chi Minh City, Vietnam . October 22-24, 2014.
Suteky, T., Dwatmadji, I. Katsiri and M. Wardanela 2016. Present Status of Livestock Disease in the Coastal Region South Bengkulu Indonesia. Proceding International Seminar and Expo Sustainable Utilization of Coastal Resource in Tropical Zone Oct 19-20, 2016. Bengkulu, Indonesia.

Wildeus, S and A. M. Zajac. 2005. Gastrointestinal Parasitism in Hair Sheep and Meat Goat BreedsGrazing Naturally Infected Pasture. Sheep \& Goat Research Journal. 20:42-46. 